\title{
The Methods and Criterion of Origen and Maximus Confessor's Exegesis in InTerpreting Scriptures' Verses on Violence: its Relevance to Prevent Radicalism and Fundamentalism
}

\author{
Agus Widodo \\ Doctoral Student in Institutum Patristicum Augustinianum, Rome, Italy. \\ aguswidodo@usd.ac.id
}

\begin{abstract}
:
Radicalism and fundamentalism, commonly characterized by acts of terror and violence, are considered as serious threats to Indonesia as a nation. One of the triggers of radical and fundamentalist movements is the misunderstanding on some verses about violence, war, and murder in the Scriptures. The radicals and the fundamentalists tend to interpret literally and use those verses to legitimate their actions. This paper has no intention to blame and to correct verses of the Scriptures that are literally provocative for violence, but to offer some inspiration from patristic tradition about how to interpret the Bible verses on violence. There are three methods and one criterion, that is, method of "esegesi orante", method of allegorical-spiritual, method of the Scripture interprets Scripture, and the criteria of $\omega \varphi c ́ \lambda \varepsilon \imath \check{\alpha}$ (ōphéleia: benefit). These methods and criterion may also be applied to interpret and to understand Koran verses on violence, as there are some provocative verses in regard to violence in both Scriptures. Moreover, Muslims also have the Tafsir (exegesis, commentary) as a methodology for reading and explaining the Koran, even accepting hermeneutics as a method of interpretation that is very relevant to understand the message of the Koran.
\end{abstract}

\section{Keywords:}

radicalism, fundamentalism, Scriptures, verses of violence, Origen, Maximus Confessor, "esegesi orante", allegorical-spiritual, benefit 


\section{INTRODUCTION}

Issues of radicalism and fundamentalism are always a popular and challenging topic to be discussed, especially when it is associated with religion. All religions are meant to teach goodness, love and peace. Islam is a peaceful religion, indicated by their concept of rahmatan li'l-'ālamīn which means mercy to all creations (Al-Anbiya' 21, 107). Christians receive and have love for God and love for neighbor as their first and greatest commandment (Mt. 34-40). However, throughout history, many acts of violence and terror have occurred in the name of religion. Religion that should be an instrument of goodness, love and peace is often manipulated to justify acts of violence and terror.

According to Azyumardi Azra, one of Indonesian Muslim scholars, radicalism is an extreme form of religious revivalism. Revivalism is an increased spiritual interest or renewal in the religious life (keislaman) which is more personal (inward oriented). Meanwhile, fundamentalism is a form of radicalism, which tend to be outward oriented, and in its application, tends to use violence. ${ }^{1}$ Fundamentalists tends to dominate the truth by claiming that they are the most accurate in understanding and applying their religious teachings, and want to force others to do the same, including by means of violence. The paper will discuss the phenomena of radicalism and fundamentalism in Indonesia and the contribution of patristic exegesis in interpreting the Scriptures. ${ }^{2}$

\section{RADiCALISM AND FUNDAMENTALISM IN INDONESIA}

In Indonesia, radicalism, fundamentalism, terrorism, and other acts of violence are usually associated with Islam. ${ }^{3}$ This is understandable because Indonesia, as stated by Darul Fattah Imdadun Rahmat, researcher of Islamic Research Institute, is a fertile land for the development of rad-

1 Azyumardi Azra, Islam Reformis: Dinamika Intelektual dan Gerakan (Jakarta: Raja Grafindo Persada 1999) 46-47.

2 Patristic exegesis refers to all the activity of interpreting the Scriptures carried out by the Fathers of the Church, both in homilies and in commentaries. Cf. M. Simonetti, s.v. Exegesis, Patristic, in Encyclopedia of Ancient Christianity, ed. Angelo di Berardino (Illionis: IVP Academic 2014) 897-903.

3 Sulistiyono Susilo \& Reza Pahlevi Dalimunthe, "Moderate Southeast Asian Islamic Education as a Parent Culture in Deradicalization: Urgencies, Strategies, and Challenges", Religions 10, 45 (2019), doi:10.3390/rel10010045 (access 23.02.2020). 
ical Islamic movements. ${ }^{4}$ In the past (1949-1962), there was Darul Islam or Islamic Armed Forces of Indonesia (DI/TII) that fought for establishment of an Islamic State in Indonesia. ${ }^{5}$ In recent years the radical Islamic movement in Indonesia is highly variable, such as Hizbut-Tahrir Indonesia (HTI), Tarbiyah-Ikhwanul Musliminan, Salafi-Wahabi Movement, Islamic Defenders Front (Front Pembela Islam - FPI), Warriors of Jihad (Laskar Jihad -LJ), Indonesian Mujahedeen Council (Majelis Mujahidin Indonesia - MMI), Islamic Congregation (Jemaah Islamiyah - JI), and so on. In addition, these radical Islamic movements also promote propaganda through schools and campuses, for example through Campus Dakwah Institute (Lembaga Dakwah Kampus - LDK) activities. A study made by the Center for the Study of Islam and Society (Pusat Pengkajian Islam dan Masyarakat - PPIM) in 2018 revealed that more than $50 \%$ of Muslim teachers who joined the LDK in university encouraged intolerant views. ${ }^{6}$

According to a 2016 survey conducted by the Wahid Foundation and the Religious Affairs Ministry, 41\% of around 1,600 respondents would support any cause to turn Indonesia into an Islamic state under a caliphate, and $60 \%$ of them would go on jihad to countries like Syria if they had a chance, while $31 \%$ of them defined jihad as a holy war against non-Muslims. ${ }^{7}$ In the same year, based on the survey of 760 students of public high schools in Jakarta and Bandung, the Setara Institute for Democracy and Peace revealed that $35.7 \%$ of the students surveyed showed a tendency towards intolerance, $2.4 \%$ of them were involved in acts of intolerance, and $0.3 \%$ of them had the potential of becoming terrorists. ${ }^{8}$ Another survey conducted by the State Intelligence Agency (Badan Intelejen Negara - BIN) in 2017, revealed that about 39\% of univer-

4 NU Online, “Indonesia Ladang Empuk Kelompok Islam Garis Keras?” (1 April 2018). https: / / www.nu.or.id/post/read/88049/indonesia-ladang-empuk-kelompok-islam-garis-keras (access 5.11.2019).

5 Cornelis van Dijk, Rebellion under the Banner of Islam. The Darul Islam in Indonesia (Leiden: Martinus Nijhoff 1981). https: / /www.jstor.org/stable/10.1163/j.ctvbqs6vx (acces 26.02.2020); Chiara Formichi, "(Re) Writing the History of Political Islam in Indonesia”, Journal of Social Issues in Southeast Asia 30, No. 1 (2015). DOI: 10.1355/sj30-ld (access 26.02.2020).

6 The Jakarta Post, "Wider student movement 'could curb' campus radicalism in Indonesia," (May 29, 2019). https://www.thejakartapost.com/news/2019/05/28/wider-student-movement-could-curb-campus-radicalism-in-indonesia.html (access 5.11.2019).

7 Ibid.

8 Ria Nurdiani, “Ministry sets up task force on campus radicalization,” (July 07 2018). https: / / www.universityworldnews.com/post.php?story $=20180707152432283$ (access 5.11.2019). 
sity students across 15 provinces in Indonesia had shown interest in radical teaching and have been exposed to radical groups. ${ }^{9}$ In addition, Ryamizard Ryacudu, former Defense Minister of Indonesia, recently revealed that about 3\% of the country's military may have been radicalized on religious grounds. ${ }^{10}$ Those surveys show that radicalism and fundamentalism are serious challenges to the Indonesian nation as President Joko Widodo remarked during the ceremony for the $73^{\text {rd }}$ National Police (Bhayangkara) Day. ${ }^{11}$

Despite those facts of radicalism and fundamentalism in Indonesia aforementioned, it is absolutely not true that radicalism and fundamentalism are always and only associated with Islam, or even identifying Islam as a radical and fundamental religion. In other countries, Christians, Hindus, Buddhist, or other religion also could be radical and fundamentalist. ${ }^{12}$ Every person of each religion has the potential to be a radical and a fundamentalist. In fact, Pope Francis stated that fundamentalism is not just an Islamic problem, "It is a disease of all religions. Catholics, we have a few, even many fundamentalists". ${ }^{13}$ After visiting three nations of Africa in late 2015, where he preached reconciliation and hope, Pope also said that, "We Catholics, we have a few, even many fundamentalists. They believe they know absolute truth and corrupt others". ${ }^{14}$

9 Ibid.

10 CNN Indonesia, "Menhan Sebut 3 Persen Anggota TNI Terpapar Radikalisme,” (19 Juni 2019). https: / / www.cnnindonesia.com/nasional/ 20190619113157-20-404549/menhan-sebut-3-persen-anggota-tni-terpapar-radikalisme (access 5.11.2019).

11 Sri Haryati, ed., "Terrorism, radicalism are still serious challenges: President Jokowi," (10 July 2019). https://en.antaranews.com/news/128737/terrorism-radicalism-are-still-serious-challenges-president-jokowi (access 5.11.2019).

12 Corneliu C. Simut, Traditionalism and Radicalism in the History of Christian Thought (New York: Palgrave Macmillan 2010); Sam Brewitt-Taylor, Christian Radicalism in the Church of England and the Invention on the British Sixties, 1957-1970:The Hope of a World Transformed (Oxford: Oxford University Press 2018); Mubashar Hasan, Kenji Isezaki \& Sameer Yasir (eds.), Radicalization in South Asia: Context, Trajectories and Implications (New Delhi, California: SAGE Publications 2019); Martijn van Beek, "Dangerous Liaisons: Hindu Nationalism and Buddhist Radicalism in Ladakh", ReseachGate (January 2004). https://www.researchgate.net/publication/288913917_Dangerous_Liaisons_Hindu_Nationalism_and_Buddhist_Radicalism_in_Ladakh (access 26.02.2020).

13 Antony Joseph, “Fundamentalism is 'a disease of all religions': Pope says it is not just Islam that has extremist factions," Mailonline (2 December 015). https://www.dailymail.co.uk/news/ article-3343363/Fundamentalism-disease-religions-says-Pope.html (access 5.11.2019).

14 Firtpost, "Pope Francis says fundamentalism is 'disease of all religions'," (1 December 2015). https: / /www.firstpost.com/world/pope-francis-says-fundamentalism-is-disease-of-all-religions-2527930.html (access 6.11.2019). 


\section{The Scriptures and Violence}

One of the reasons, which is often used to explain why a number of radical groups commit violence is the Scriptures. Islamic radicals and fundamentalists, for example, discovered and exploited a number of verses in the Koran, especially the verses concerning jihad, to justify their acts of violence. Many studies confirm that radical and fundamentalist groups of any religion tend to understand and interpret the Scriptures rigidly and literally (Scripturalism). ${ }^{15}$ Convincing that the Scriptures are the words of God, they believe that it is free from any sort of error (inerrancy) and it needs no interpretation since the human mind is unable to provide the correct interpretation. Therefore, radicals and fundamentalists also reject hermeneutics and critical study of the Scriptures since they perceive that what is written in the Scriptures must be understood literally and must be used as a term of reference for attitudes and behavior without any consideration.

However, verses about violence, murder, and war are not discovered only in the Koran, but also in the Bible, which surprisingly has even more verses related to that matter. ${ }^{16}$ In fact, the Old Testament contains some very detailed stories about violence, murder, war, and destruction. For example the story of the conquest of Canaan by the Israelites under the leadership of Joshua (Jos. 6, 1-27) and the story of the assassination of King Saul's descendants by the Gibeonites (2 Sam. 21, 1-14). The New Testament also displays several teachings of Jesus, which contain hostility and contention, for example in $L k$. 12, 51-53.

15 Muhamad Harfin Zuhdi, "Fundamentalisme dan Upaya Deradikalisasi Pemahaman Al-Qur'an dan Hadis", Religia 13, Nr. 1 (2010) 81-102; Yusril Ihza Mahendra, Modernisme dan Fundamentalisme dalam Politik Islam; Perbandingan Partai Masyumi (Indonesia) dan Partai Jamâ'at-i-Islâmî (Pakistan), (Jakarta: Paramadina 1999) 29; Hamim Ilyas, "Akar Fundamentalisme dalam Perspektif Tafsir Al-Quran”, Kata Pengantar in Jack Nelson Pallmayer, Is Religion Killing Us?: Membongkar Akar Kekerasan dalam Bibel dan Qur'an, trans. \& ed. Hatib Rachmawan, Bobby Setiawan, and Iskandar Zulkarnain (Yogyakarta: Pustaka Kahfi 2007) xvii; Steve Bruce, Fundamentalism, (Cambrigde: Pality Press 2000) 13-15.

16 In a comparative analysis, using an advanced data-mining platform namely OdinText, Tom $\mathrm{H}$. C. Anderson revealed that the Old Testament seems to contain the most narratives of violence. It mentions $5.3 \%$ of the words "murder and destruction", more than twice that of the Koran, which is only $2.1 \%$, while the New Testament has slightly more $(2.8 \%)$ than the Quran. Tom H.C. Anderson, "Text analysis answers: Is the Quran really more violent than the Bible? (Part 2 of 3)," (20 January 2016). https://odintext.com/blog/blog/textanalysisbible2of3 (access 5.11.2019). 
Considering that both the Koran and the Bible contain verses and narratives related to violence, war, destruction and killing, Christians and Muslims actually face the same problems relating to radicalism and fundamentalism. At the same time, both religions face the same risk of the growth and development of radical and fundamentalist groups because their Scriptures present some verses for provoking and justifying their acts of violence. Nonetheless, both Christians and Muslims can work together to prevent radicalism and fundamentalism by learning reciprocally to provide the appropriate interpretation and application, especially about the verses and narrations of violence in the Scriptures.

\section{Origen and Maximus Confessor's Interpretation on Verses of VIOLENCE}

Both Christians and Muslims are very respectful to their Scriptures because they are seen as the words and revelations of God. Christians never doubt the validity and authenticity of the Bible as a source of the doctrines as well as an ethical and moral foundation. Likewise, every Muslim is assured that the Koran and Hadith are the valid and authentic sources for every doctrine as well as solid foundations for their ethical and moral rules. For Christians, "All scripture is inspired by God and profitable for teaching, for reproof, for correction, and for training in righteousness, that the man of God may be complete, equipped for every good work. (2 Tim. 3, 16-17, RSV). For Muslims, the Prophet Muhammad has given the Koran and Hadith as guidelines for life, saying, "I leave you two things, you will not go astray as long as you hold on to both: the Book of Allah and the Sunnah of His Prophet". ${ }^{17}$ If that is the case, how should we understand and apply any violence narrative or command, so that the Scriptures can truly be a reference to do good work and to avoid straying from the principal message?

Of course, it is out of place to question and to blame the Koran and the Bible, even to say that the violence verses and narrations are the "sins of the Scriptures", as John Shelby Spong, a retired bishop of the Anglican Church of Newark, New Jersey and a liberal Christian theo-

17 Hadits Shahih Lighairihi, H.R. Malik; al-Hakim, al-Baihaqi, Ibnu Nashr, Ibnu Hazm. Dishahihkan oleh Syaikh Salim al-Hilali di dalam At Ta'zhim wal Minnah fil Intisharis Sunnah, 12-13. https: / / muslim.or.id/6966-kaedah-penting-dalam-memahami-al-quran-dan-hadits.html. (access 5.11.2019) 
logian, did. ${ }^{18}$ It is very unfair also to judge that the, "The Bible, of all Books, is the most dangerous one, the one that has been endowed with the power to kill”, as Mieke Bal, a Dutch literary theory professor, said. ${ }^{19}$ What needs to be corrected are certainly not the Scriptures, but the understandings of people who interpret, and apply the violence verses of the Scriptures. The following pages present examples of the Origen and Maximus Confessor's interpretations on the three Bible texts that contain narratives about violence. Their methods of interpretation might also be able to contribute to interpreting and to understanding the Koran verses on violence since Muslims also use "Tafsir" (exegesis, commentary) as a methodology for reading and explaining the Koran. ${ }^{20}$ Moreover, some of them also accept the hermeneutics as a very relevant and useful method to interpret the Koran's and to understand God's message comprehensively with the subtilitas intellegendi (accuracy of understanding) and the subtilitas explicandi (accuracy of translation/ explanation). ${ }^{21}$ For that reason, several Islamic Universities such as the State Islamic University (UIN) Jakarta, UIN Bandung, and UIN Yogyakarta have determined the hermeneutics as a compulsory subject in the Hadiths Interpretation Department.

\section{Origen's interpretation on Joshua 6, 1-27}

The Book of Joshua describes the conquest of Canaan and its allotment to the Israelite tribes, under the leadership of Joshua, who gave detailed step-by-step instructions to the people of Israel on how to conquer Canaan.

Now Jericho was shut up from within and from without because of the people of Israel; none went out, and none came in. And the Lord said to Joshua, "See, I have given into your hand Jericho,

18 John Shelby Spong, The Sins of Scripture: Exposing the Bible's Texts of Hate to Reveal the God of Love, (NY: HarperOne; HarperCollins), 2005.

19 Mieke Bal, ed., Anti-Covenant: Counter-Reading Women's Lives in the Hebrew Bible, (Sheffield: The Almond Press 1989) 14.

20 The word "tafsir" (pl. tafasir) is a noun derived from the verb "fassara/yufassiru", which means explanation, exposition, elucidation, explication, interpretation and commentary. Technically, "tafsir" is the term encompassing both scholarly efforts to explain the Koran and make it more understandable and also the branch of Islamic science that deal with it. Cf. Adnan Demircan \& Rifat Atay, s.v. Tafsir in Early Islam, in The Qur'an:An Encyclopedia, ed. O. Leaman (London \& New York: Routledge 2006) 624-631.

21 A. Fuad Fanani, “Metode Hermeneutika untuk Al-Qur'an” (17 Februari 2002). http: / /islamlib. $\mathrm{com} / \mathrm{kajian} /$ quran/metode-hermeneutika-untuk-al-quran/ (access: 26.02.2020). 
with its king and mighty men of valor. You shall march around the city, all the men of war going around the city once. Thus shall you do for six days. And seven priests shall bear seven trumpets of rams' horns before the ark; and on the seventh day you shall march around the city seven times, the priests blowing the trumpets. And when they make a long blast with the ram's horn, as soon as you hear the sound of the trumpet, then all the people shall shout with a great shout; and the wall of the city will fall down flat, and the people shall go up every man straight before him." So Joshua, the son of Nun, called the priests and said to them, "Take up the ark of the covenant, and let seven priests bear seven trumpets of rams' horns before the ark of the Lord." And he said to the people, "Go forward; march around the city, and let the armed men pass on before the ark of the Lord." And as Joshua had commanded the people, the seven priests bearing the seven trumpets of rams' horns before the Lord went forward, blowing the trumpets, with the ark of the covenant of the Lord following them. And the armed men went before the priests who blew the trumpets, and the rear guard came after the ark, while the trumpets blew continually. [...] On the seventh day they rose early at the dawn of day, and marched around the city in the same manner seven times: it was only on that day that they marched around the city seven times. And at the seventh time, when the priests had blown the trumpets, Joshua said to the people, "Shout; for the Lord has given you the city! [...]." So the people shouted, and the trumpets were blown. As soon as the people heard the sound of the trumpet, the people raised a great shout, and the wall fell down flat, so that the people went up into the city, every man straight before him, and they took the city. Then they utterly destroyed all in the city, both men and women, young and old, oxen, sheep, and asses, with the edge of the sword. [...] Joshua laid an oath upon them at that time, saying, "Cursed before the Lord be the man that rises up and rebuilds this city, Jericho. At the cost of his first-born shall he lay its foundation, and at the cost of his youngest son shall he set up its gates." So the Lord was with Joshua; and his fame was in all the land. (Jos. 6,19.15-16.20-21.26-27, RSV).

Literally, this passage describes in detail a violence narrative, presenting Joshua and God as the main actors, since it was said at the end of the story that, "the Lord was with Joshua" (Jos. 6, 27). Joshua commanded the people to attack and to destroy the city of Jericho, while killing all its inhabitants. However, the Church Fathers never saw this story as a historical event, since they saw Joshua as the typos of Jesus and not as the historical figure. For example, Origen stated that the Book of Joshua "does not so much indicate to us the deeds of the son of Nun, as it 
represents for us the mysteries of Jesus my Lord" (Homilies on Joshua 1, 3). ${ }^{22}$ Moreover, although the Book of Joshua was placed in the group of historical literature, but the historicity of this book cannot simply be accepted since it simplified a long and complex process of occupation of the land by the Israelite tribes.

One of the Church Fathers who wrote a complete commentary on the Book of Joshua was Origen (c.a. 185-254). ${ }^{23}$ He was the founder of the Biblical Study as a serious discipline since he was the first Church Father who made the biblical exegesis as a systematic work and theorized it. ${ }^{24}$ In Book IV, of his theological treatise entitled On First Principles, in fact, he wrote a richly and articulated exposition dedicated to the Scripture. ${ }^{25}$ First of all, he confirmed its characters, i.e. the divine inspiration and the unity of the two Testaments. Then its plurality senses that consist of literal or historic, moral, spiritual and Christological senses. Further, its levels of interpretation that includes the direct-superficial (literal-historic) and the indirect-profound (spiritual), also its methods of interpretation that covers the literal method, the typology and allegory methods, the so-called "esegesi orante" method and the method of interpreting the Scripture with the Scripture (Scripture interprets Scripture). The last, its ophéleia criterion of interpretation that means provide spiritual benefit to both the interpreter and the audience or the readers.

In regards to the story of the destruction of the city of Jericho, his interpretation was totally allegorical and spiritual. ${ }^{26} \mathrm{He}$ claimed that Jericho is the representation of the world. To support his interpretation, he mentioned two other verses that also speak of Jericho.

22 Origen, Homilies on Joshua, trans. \& ed. Barbara J. Bruce \& Cynthia White (Washington D.C.: The Catholic University of America Press 2002) 29. Other Church Fathers also attributed Joshua as typos of Jesus, for example Justin Martyr, Tertullian, Eusebius, Augustine, etc. Cf. Jean Danielou, From Shadows to Reality. Studies in the Biblical Typology of the Fathers (London: Burns \& Oates 1960) 229-243.

23 Origen, Homilies on Joshua, 74-84.

24 For the biography of Origen, see: Pierre Nautin, Origène. Sa vie e son oeuvre (Paris: Beauchesne 1977); Joseph W. Trigg, Origen (London \& New York: Routledge 1998).

25 Origen, On First Prinsiples, Book IV, trans. J. Behr (Oxford: Oxford University Press 2017) 458-561; Manlio Simonetti, Origene esegeta e la sua tradizione (Brescia 2004) 13-27; Francesca Cocchini, Origene. Teologo esegeta per una identità cristiana (Bologna 2006) 15-31.

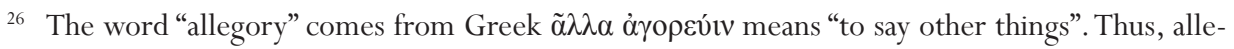
gorical interpretation is a process to understand and to gain the meaning of word or sentence that literally says something but actually wants to say something else. 
We frequently find Jericho to be placed in Scripture as a figure of this world. For also in the Gospel it is said that, "a man had descended from Jerusalem to Jericho and had run into thieves." (Lk. $10,30)$. This is undoubtedly a type of that Adam who was driven from paradise into the exile of this world. But also the blind men who were in Jericho, those to whom Jesus came in order that he might make them see (Mt. 20, 29-30), bore the sign of those who continue to be overwhelmed in this world by the blindness of ignorance, to whom the Son of God comes. (Homilies on Joshua 4, 4). ${ }^{27}$

This interpretation method is known as the Scripture interprets Scripture (Scriptura scripturae interpres) method, i.e. interpreting a verse with another verse that has lexical or conceptual similarities. ${ }^{28} \mathrm{In}$ this case, he used Lk. 10, 30 and Mt. 20, 29-30 that talked about Jericho to confirm his interpretation on the same word, "Jericho", in Jos. 6, 1-27.

There was a strong wall that surrounded and protected the city of Jericho. This wall is a symbol of the evil power manifested in the worship of idols, the deceit of magicians and the false teachings of the heretics (Origen used the word "philosophers"). ${ }^{29}$

The strength and defenses that world used as walls was the worship of idols, the deceit of divinations directed by the skill of demons and devised by diviners, soothsayers, and magicians. By all these most powerful walls, as it were, this world was encircled. Moreover, as though with certain tall and strong towers, it was also fortified with diverse dogmas of philosophers and the most eminent assertions of contentions. (Homilies on Joshua 7, 1). ${ }^{30}$

This was the reality of the situation of the world. According to Origen, this contaminated world should be destructed and then be reconstructed as a new world. The destruction of Jericho occurred under the 19, 15: "A matter must be established by the testimonies of two or three witnesses." In fact, in his Homilies on Jeremiah 1, 7, he stated that the interpretation of a verse of the Scripture should be confirmed by testimonies, one from the Old Testament and one from the New Testament, or from the Torah, the Prophets, and the Epistles of the Apostles. Origen, Homilies on Jeremiah, trans. John Clark Smith (Washington D.C.: The Catholic University of America Press 1998) 9.

29 One of Origen's aims almost in all his writings and homilies is to refute the major heresies of his time such as gnosticism and marchionism, also to answer the philosophers' questions or to correct their views which were opposed to the Christian faith or to defend Christianity from some philosophers' accusations of ignorance and foolishness.

30 Origen, Homilies on Joshua, 74. 
leadership of Joshua. For Origen, Joshua is the representation of Jesus' figure who will come for the second time at the end of the age to destroy the old world and to build the new one as described in the Book of Apocalypse (Apoc. 21-22). He will come to destroy and to defeat the devil and all of his works, such as idolatry and heretics' teaching.

When our Lord Jesus Christ comes, whose arrival that prior son of Nun designated, he sends priests, his apostles, bearing trumpets hammered thin, the magnificent and heavenly instruction of proclamation. [...] he casts down the walls of Jericho and all the devices of idolatry and dogmas of philosophers, all the way to the foundations. (Homilies on Joshua 7,1 )..$^{31}$

It can be noted that, while interpreting allegorically these violence narratives, Origen considered that this story does not speak of the past, viz. the history of the destruction of Jericho, but of the future (eschatology), i.e. the destruction and renewal of the world at the end of the age.

Further, he also declared that this passage does not only talks about eschatology, but also talks about the present, i.e. about the Church and the Christians at his time. It was described, to destroy the city of Jericho, Joshua fought together with the priests and the Israelites. The priests blew the trumpets and all the people shouted with a great shout. The trumpets' sound is the symbol of the Holy Scripture that should be contemplated by the priest and then be proclaimed to the people. Meanwhile, the great shout by the Israelites is the symbol of the unity and harmonious prayer of the faithful for the coming of the Christ to cast down the devil and to renew the world.

Every one of us ought to accomplish this in ourselves. You have in you, through faith, Jesus the leader. If you are a priest, make for yourself trumpets hammered thin [...] from the Holy Scriptures. [...]; if you demand from yourself the harmony of the joyful shout [...]; if these things within you are now harmonious and united, then send forth the sound of a joyful shout, because for you the world has been overthrown and cast down. (Homilies on Joshua 7 , 2). ${ }^{32}$

Origen was convinced that Jesus is always present in the heart of every believer. When the priests proclaim the Scriptures and the faithful shout together with a great shout, i.e. pray together in unite and har-

31 Origen, Homilies on Joshua, 74-75.

32 Origen, Homilies on Joshua, 76-77. 
monious voice, then God will give His grace to defeat and to destroy the power of evil, both in the world and in the heart. The battle against the devil is not only an event of the past but also occurs at the present time. Therefore, Origen's allegorical interpretation for this violence story of the Scriptures makes this story concrete and valuable for the listeners.

This violence story becomes useful and provides the benefits because of two factors. First, Origen has set it free from its provocative message for violence. Second, he has made the story concrete and valuable to encourage the believers in their battle to defeat and to destroy the evil spirit. For Origen, a good and correct interpretation of the Scriptures should provide a benefit or $\dot{\omega} \varphi \hat{\varepsilon} \lambda \varepsilon ı \breve{\alpha}$ (ōphéleia: benefit) for both the interpreter and the listeners, because the Scriptures, "were written for our sake" (On First Principles IV, 2, 6). ${ }^{33}$

Another important aspect of Origen's exegetical method is prayer. Realizing that this passage was very difficult, he asked his listeners to pray for him so that he could interpret and explain this text correctly according to the will of God.

What we are doing may be rash, attempting to explain passages of Scripture so arduous and so difficult. But if you aid us with your prayers, not only shall we escape the fault of audacity, but also, having embraced our devotion, God, the Father of the Word, will give the word into our open mouths, so that you may be edified and we may not appear impious. Listen, therefore, while you pray with attentive spirits. (Homilies on Joshua 8, 2). ${ }^{34}$

For Origen and for all of the Church Fathers the process of interpreting the Scriptures is similar to the process of writing it. It is not merely the work of humans, but substantially is the work of the Holy Spirit. Therefore, prayers to ask for the gift of the Holy Spirit should accompany the process of interpreting the Scriptures. In addition, the Scriptures are the words of God, so it should be interpreted according to His will. With intensive prayers, both by the interpreter and by the listeners, God will send His Holy Spirit to communicate all things and to remind everything Jesus has said (John 14, 16). This process of interpretation is well known as "esegesi orante". ${ }^{35}$

33 Origen, On First Principles, 503.

34 Origen, Homilies on Joshua, 86.

35 For the "esegesi orante", see L. Perone, La preghiera secondo Origene, l'impossibilità donata (Brescia: Morcelliana 2001) 283-290; 303-312; 314-322; 331-339; 371-385; Daniel Sheerin, The Role of 


\section{Maximus the Confessor's interpretation on 2 Samuel 21, 1-14}

The two Books of Samuel, in which can be found many stories of war and murder, describes the beginning of the Israel monarchy and the reigns of its first two kings, Saul and David. One of those stories is the assassination of Saul's descendants by the Gibeonites.

Now there was a famine in the days of David for three years, year after year; and David sought the face of the Lord. And the Lord said, "There is bloodguilt on Saul and on his house, because he put the Gibeonites to death." So, the king called the Gibeonites. Now the Gibeonites were not of the people of Israel, but of the remnant of the Amorites; although the people of Israel had sworn to spare them, Saul had sought to slay them in his zeal for the people of Israel and Judah. And David said to the Gibeonites, "What shall I do for you? And how shall I make expiation, that you may bless the heritage of the Lord?" The Gibeonites said to him, "It is not a matter of silver or gold between us and Saul or his house; neither is it for us to put any man to death in Israel." And he said, "What do you say that I shall do for you?" They said to the king, "The man who consumed us and planned to destroy us, so that we should have no place in all the territory of Israel, let seven of his sons be given to us, so that we may hang them up before the Lord at Gibeon on the mountain of the Lord." And the king said, "I will give them." But the king spared Mephibosheth, the son of Saul's son Jonathan, because of the oath of the Lord which was between them, between David and Jonathan the son of Saul. The king took the two sons of Rizpah the daughter of Aiah, whom she bore to Saul, Armoni and Mephibosheth; and the five sons of Merab the daughter of Saul, whom she bore to Adriel the son of Barzillai the Meholathite; and he gave them into the hands of the Gibeonites, and they hanged them on the mountain before the Lord, and the seven of them perished together. They were put to death in the first days of harvest, at the beginning of barley harvest. Then Rizpah the daughter of Aiah took sackcloth, and spread it for herself on the rock, from the beginning of harvest until rain fell upon them from the heavens; and she did not allow the birds of the air to come upon them by day, or the beasts of the field by night. When David was told what Rizpah the daughter of Aiah, the concubine of Saul, had done, David went and took the bones of Saul and the bones of his son Jonathan from the men of Jabeshgilead, who had stolen

Prayer in Origen's Homilies, in Origen of Alexandria. His World and His Legacy, edd. C. Kannengieser-W. L. Petersen, Notre Dame 1988, 200-214. 
them from the public square of Bethshan, where the Philistines had hanged them, on the day the Philistines killed Saul on Gilboa; and he brought up from there the bones of Saul and the bones of his son Jonathan; and they gathered the bones of those who were hanged. And they buried the bones of Saul and his son Jonathan in the land of Benjamin in Zela, in the tomb of Kish his father; and they did all that the king commanded. And after that God heeded supplications for the land. (2 Sam. 21,1-14, RSV).

A literal reading of this text could potentially provoke acts of violence. This text could be easily used as an example and justification for revenge. However, since the beginning, the Christians tried to examine and figure out its spiritual meaning. For example, Thalassios († 648), a Libyan priest and abbot, while examining this text and having difficulty in figuring out its spiritual meaning, he then asked Maximus the Confessor: "What is the meaning of these words, and how might we contemplate them spiritually?" 36

Maximus the Confessor (ca. 580-662) was widely recognized as one of the greatest Church Fathers and Byzantine theologians. ${ }^{37} \mathrm{He}$ lived during the most catastrophic period of the Byzantine Empire before the Crusades (1095/6-1291). During his period, the reigns of the emperors in Constantinople stood in the shadows cast by the fall-out after the Chalcedon Council (451) and the increasing dangers provoked by Avars, Slavs, Persians, and Arabs. Therefore, he experienced the violent and dreadful events around the fall of Damascus and Emesa to the Muslims in 635 , followed by the fall of Syria. Jerusalem was surrendered to the Arabs by Patriarch Sophronius in 637 or 638.

Regardless, those situations did not influence Maximus to use these violent verses of the Scriptures to provoke and to generate other violence. In his answer to Thalassios, preserved in On Difficulties in Sacred Scripture: The Responses to Thalassios (well known also as The Responses to Thalassios), he interpreted this story in allegorical and spiritual ways. ${ }^{38}$ He began his answer by asserting that,

36 Maximus the Confessor, On Difficulties in Sacred Scripture: The Responses to Thalassios, trans. Maximos Constas (Washington D.C.: The Catholic University of America Press 2002) 519.

37 For the biography of Maximus the Confessor, see: Andrew Louth, Maximus the Confessor (London \& New York: Routledge 1996); Pauline Allen \& Bronwen Neil, ed. The Oxford Handbook of Maximus the Confessor (Oxford: Oxford University Press 2015)!

38 For the spiritual exegesis of Maximus, see: Paul M. Blowers, Exegesis and Spiritual Pedagogy in Maximus Confessor: An Investigation of the Quaestiones ad Thalassium (Notre Dame: University of 
The precise knowledge of the words of the Spirit is of a nature to be revealed only to those who are worthy of the Spirit, who on account of their great diligence in virtue have purified their intellect from the grimy soot of the passions, making it like a clear and shining mirror, so that with a single glance they receive the knowledge of divine realities reflected within themselves like a face. (On Difficulties in Sacred Scripture 65, 2). ${ }^{39}$

With this answer, Maximus underlined that the Scriptures are the words of the Spirit, since the Holy Spirit inspired its human writers. Consequently, the Scriptures should be interpreted spiritually, and to do so the interpreter should be worthy of the Spirit. It means, the interpreter should have purified his mind and freed his heart from all evil passions. This is the first and foremost condition for interpreter to be able to interpret the Scripture in accordance with the intention of the Holy Spirit. The process of purifying heart and mind so that he is ready to receive the gift of the Holy Spirit could be paralleled to the "esegesi orante" of Origen.

Maximus then began his spiritual interpretation by indicating the meaning of the names of each personage, started by the meaning of Saul, then his concubine, and his descendants.

Saul, in this passage of Scripture, signifies the written law, [...] the corporeal way of life or thinking that rules over those who are guided solely by the letter of the law. [...] Saul's concubine, Rizpah, means the "course of the mouth." [...] The person who occupies himself solely with the corporeal observance of the law, unlawfully cohabits with such learning, and from their union is born nothing that is pious or loves God. [...] From his illicit coupling with Rizpah, Saul became the father of Armoni and Mephibosheth, whose names mean "anathema on them" and "shame of their mouth". [...] "Anathema on them" is the sinful corruption that occurs in the body due to the activity of the passions. "Mephibosheth" is the unnatural movement of the intellect toward evil. [...] Merab translated means "filling of the throat," which is gluttony. [...] Adriel translated means "divine power" or "strong help" or "powerful sight," which signifies the intellect as the image of God. [...] Having been persuaded to cohabit with gluttony, which is the offspring of the law subordinated to the flesh, by which I mean the letter, [...] it will cohabit with nothing else but gluttony, believing it to be divine and the offspring of the royal law, and from it he will bring

Notre Dame Press 1991).

39 Maximus, On Difficulties in Sacred Scripture ..., 520. 
forth various ways of misusing his bodily senses. (On Difficulties in Sacred Scripture 65, 3-8). ${ }^{40}$

From those meanings of Saul's name and his families', it could be concluded that all of those names refer to the corporal way of life, i.e. the life that is only based on the literal interpretation of the law. It became clearer when Maximus explained the meaning of Gibeonites as "mountainous" or "raised up", viz., "the loftier principles of natural contemplation" (On Difficulties in Sacred Scripture 65, 9). ${ }^{41}$ Thus, Saul's slaughter against the Gibeonites is a symbol of the literal interpretation that casts away the contemplation and the spiritual interpretation of the Scriptures. This situation caused a famine, which spiritually means lacking truth or "divine knowledge in the spirit [...]. In this case, a famine is the privation of good things known through experience, and a shortage and utter scarcity of the spiritual nourishment that sustains the soul" (On Difficulties in Sacred Scripture 65, 12). ${ }^{42}$

When there was a famine in Israel after the death of Saul, David sought the face of the Lord. Lord said that the famine was caused by the sin of Saul who killed the Gibeonites. Therefore, David discussed with the Gibeonites, and they demanded seven of Saul's descendants to be killed and their bodies to be exposed before the Lord at Gibeah of Saul as sacrifice. The assassination of Saul's descendants by the Gibeonites is a symbol of the spiritual interpretation that casts away the literal interpretation of the Scriptures. In addition, the name of David, according to Maximus, means "destruction", "contempt" and "powerful in vision", and in this case means the destruction of the literal interpretation of the Scriptures and the victory of the spiritual interpretation (On Difficulties in Sacred Scripture 65, 12). ${ }^{43}$

Through this allegorical-spiritual interpretation, Maximus transformed a biblical violence story, the assassination of Saul's descendants, into another definition which is the destruction of the literal interpretation of the Scriptures. The literal interpretation should "be hated and expelled" (On Difficulties in Sacred Scripture 65, 29), ${ }^{44}$ because it could

40 Maximus, On Difficulties in Sacred Scripture ..., 520-523.

41 Maximus, On Difficulties in Sacred Scripture ..., 524.

42 Maximus, On Difficulties in Sacred Scripture ..., 526.

43 Maximus, On Difficulties in Sacred Scripture ..., 526-527.

44 Maximus, On Difficulties in Sacred Scripture ..., 543. 
potentially provoke the souls and intellectuals to desire the evil and violence. However, it should be noted, that in this case, Maximus did not reject the historical and literal meaning of the verses he interpreted, but considered it to be irrelevant, even dangerous, so it should be ignored. ${ }^{45}$ One of the ways to decide whether the literal meaning of verses is relevant or not is by examining the message: is it in accordance with the nature and the will of God, is it in accordance with the main and general message of the Scriptures, does it have a good impact on human life? God is the supreme good. He wants the goodness of all His creation, and the general message of the Scriptures is love. Therefore, the messages from literal interpretation of the verses that are not in accordance with the concept of goodness and love, should be considered irrelevant and should be ignored. ${ }^{46}$

\section{Origen's interpretation on Luke 12, 51-53}

One more example of the patristic interpretation is taken from the New Testament, Lk. 12, 51-53, which presents the teaching of Jesus about His coming that brings division

Do you think that I have come to give peace on earth? No, I tell you, but rather division; for henceforth in one house there will be five divided, three against two and two against three; they will be divided, father against son and son against father, mother against daughter and daughter against her mother, mother-in-law against her daughter-in-law and daughter-in-law against her mother-inlaw." (Lk 12,51-53, RSV)

Literally, this teaching of Jesus contradicts with His main message of love and peace. How come Jesus who teaches about love for God and love for other as the main law, at the same time said that He did not come to bring peace but rather division? Likewise, linked to the context of Jesus' teaching about discipleship, the calling to follow Jesus certainly does not

45 Manuel Mira Iborra, "La Uccisione dei discendenti di Saul (2 Sam. 21, 1-14) nella Quaestio ad Thalassium LXV," Cristianesimo e violenza: gli autori cristiani di fronte a testi biblici 'scomodi'. XLIV Incontro di Studiosi dell'Antichità Cristiana: Roma, 5-7 maggio 2016 (Roma: Institutum Patristicum Augustinianum 2018) 227.

46 Different from Marcion who not only refuses the messages of the Scriptures but also the entire Old Testament and only accepts the Gospel of Luke and ten epistles of Paul (Romans, 1 and 2 Corinthians, Galatians, Ephesians, Philippians, Colossians, 1 and 2 Thessalonians, Philemon), Maximus Confessor accepts the whole of Scriptures, both the Old and the New Testament. He refuses only the messages from the literal interpretation of the verses that are not in accordance with the concept of goodness and love because for him are irrelevant. 
mean hostility towards family members. Therefore, the literal interpretation of this text should be irrelevant.

Origen, while accepting that this text could be interpreted literally, was more interested in allegorical and spiritual interpretation. The oppositions in this text clarify the conflict and division between believers and unbelievers. Origen however ignored this literal interpretation by immediately explaining his allegorical interpretation, and started by discussing the meaning of individuals mentioned by Jesus.

The persons named in the Gospel are six in number. But one person, the daughter-in-law, counts for two. The daughter-in-law and the daughter, who oppose the mother and the mother-in-law, are the same person. And thus, he opposes three to contend against two, and two to contend against three. By way of comparison, in a house (that is, a man), the five senses are unanimous in their pleasures before the Word comes to them, but divided when the Word dwells there. Two are the more philosophical senses: sight, by which we see the world and its order and wonder at the Creator; and hearing, through which the Word of God makes us disciples. Then there are the other three senses: taste, smell, and touch, which are servile and not by nature suited for philosophy. The three usually oppose the two. But the phrase, "father will be divided against son", should be read from another principle, not from the one just explained. Literally, the phrase makes clear the division of believers from unbelievers. Symbolically, however, "father", the mind, is divided against "son", worthless passion, and does not give assent to it. "And son against father": the son does not bury his dead father. "Mother against daughter": the soul does not receive the daughter's worthless fruit. "Daughter against mother": the soul has not yet united matter with itself. "Mother-in-law against daughter-in-law": the mother of the soul, who lived under the Law as her husband (by "the mother of the soul" I mean the Holy Spirit), deserts the people of the circumcision. "Daughter-inlaw against mother-in-law": the people separated from the Spirit through sin." (Fragments on Luke, 202). ${ }^{47}$

The father symbolizes the human mind and the son symbolizes worthless passions. Thus, the opposition between father and son means the conflict between the mind and the worthless passions. The mind would not allow the worthless passions to dominate the human being and the

47 Origen, Homilies on Luke, Fragmens on Luke, trans. Joseph T. Lienhard (Washington D.C.: The Catholic University of America Press 1996) 208-209. 
worthless passions would not be allowed burying the mind. Linked to the context of Jesus' teaching about discipleship, only the person, whom with his mind is able to control his worthless passions and does not allow his mind to be buried by worthless passions, would be the true disciple of Jesus.

The mother symbolizes the soul and the daughter symbolizes worthless fruit, which is acts of vanity or sins. Thus, the conflict between mother and daughter symbolizes the battle of the soul against sin or evil deeds. The soul is the most sublime part of man, created as the image of God. ${ }^{48}$ Based on Paul's tripartite view of humans that consist of spirit, soul and body (1 Thess. 5, 23), Origen reveals that the soul, in which the free will is, could be directed to follow the desires of the Spirit or the desires of the flesh. ${ }^{49}$ Linked to the context of Jesus' teaching about discipleship, only the person, who takes care of his soul by obeying the desires of the Spirit and does not allow it to be dominated by sins and to be tainted by the desires of the flesh, would be the true disciple of Jesus.

Mother-in-law symbolizes the mother of soul, i.e. the Holy Spirit, and daughter-in-law symbolizes the Jews (Origen called them the people of the circumcision). Thus, the conflict between mother-in-law and daughter-in-law symbolizes the Spirit who deserts the people of the circumcision because they close the heart to the work of the Holy Spirit. They tend to understand the Law and the Scriptures literally and refuse the spiritual sense of the Law and the Scriptures. Furthermore, they also rejected Jesus who was conceived by the power of the Holy Spirit and was born by the Virgin Mary as the Messiah. In addition, Origen said that the daughters-in-law who oppose the mother-in-law are the people who are separated from the Spirit because of their sins.

With this interpretation, Origen reveals, while these verses could be interpreted literally, it should be scrutinized in its spiritual meaning, which are often hidden behind the texts. In his other work, he stressed that,

48 Giulia Sfameni Fasparo, “Anima,” Origene. Dizionario: la cultura, il pensiero, le opere, ed. Adele Monaci Castagno (Roma: Città Nuova 2000) 18.

49 Gal 5, 19-23: The acts of the flesh are obvious: sexual immorality, impurity and debauchery; idolatry and witchcraft; hatred, discord, jealousy, fits of rage, selfish ambition, dissensions, factions and envy; drunkenness, orgies, and the like. I warn you, as I did before, that those who live like this will not inherit the kingdom of God. But the fruit of the Spirit is love, joy, peace, forbearance, kindness, goodness, faithfulness, gentleness and self-control. 
"The scriptures were written by the Spirit of God, and that they have not only that meaning which is obvious, but also another which escapes the notice of most. For the things that are described [therein] are the form of certain mysteries and images of divine things. There is one mind throughout the entire church about this, that the whole law is indeed spiritual (Rom. 7, 14), yet that which the law conveys is not known by all but only by those on whom the grace of the Holy Spirit is bestowed in the words of wisdom and knowledge." (On First Principles I, Preface 8). ${ }^{50}$

Origen asserted that all the Scriptures, which means all the books, chapters and verses, since they were written by the Spirit of God, have spiritual meaning. Among these spiritual meanings, some are immediately apparent in words and sentences, but mostly are hidden behind texts. Therefore, although the historical narratives in the Scriptures could be interpreted literally, the interpreters should not stop and be satisfied after obtaining the literal meaning, especially if the meaning is not in accordance with the principal teachings of God. They should continue looking for the deeper meaning, i.e. the spiritual meaning. In fact, Origen compared the Scriptures with almonds and the process of interpreting with the process of peeling them. Its shells taste bitter and certainly should not be eaten. This is the literal sense of the Scriptures. What is eaten and tastes good is the kernel inside the shells. This is the spiritual meaning of the Scriptures. ${ }^{51}$

The spiritual meanings, which are very often hidden behind the texts and the historical narratives, should be discovered through the allegorical interpretation. However, in order for the allegorical interpretation to produce the spiritual meaning as intended by the Holy Spirit, interpreters should have the gifts of the Holy Spirit, specially the spirit of wisdom, understanding, and knowledge. Thus, the process of interpretation of the Scriptures should be an "esegesi orante", because only by prayers interpreters would have the gifts of the Holy Spirit.

\section{Conclusion Remarks}

Most perpetrators of terrorist acts, suicide bombings, murders, wars and other forms of violence in the name of religion come from the rad-

50 Origen, On First Principles 19.

51 Origen, Homilies on Numbers 9, 7.3, trans. \& ed. Thomas P. Scheck \& Christopher A. Hall (Illionis: InterVarsity Press 2009) 42. 
ical and fundamentalist groups. They do not have any guilty feeling for their acts of violence. On the contrary, they feel that it was necessary to be done because they have a justification and legitimacy from the Scriptures. This happens because materially, in the Scriptures such as the Bible and the Koran, there are provocative verses and narratives to trigger and justify the acts of violence. This study on patristic exegesis offers an alternative interpretation method that could set the Scriptures away from its provocative messages for violence.

There are three important methods and one criterion of interpretation in patristic exegesis applied by the Church Fathers such as Origen and Maximus the Confessor. First, the so-called "esegesi orante" method i.e. the process of interpreting the Scriptures that is preceded by prayer and carried out in prayer. It means the prayer is not only the preliminary step of interpretation but also during the interpretation process. ${ }^{52}$ This method should be very important because the Scriptures are not a simply human writing. While the Scriptures were written by humans, it was God who chose them and the Holy Spirit who inspired them to write down the words of God. Hence, to interpret the Scriptures correctly according to God's will, interpreters should have the inspiration from the same Holy Spirit, which had inspired the writers. This is only possible if the process of interpreting the Scriptures is done in prayer.

Second, there is the allegorical-spiritual method. The Scriptures are not simply a human literature but are sacred and spiritual books. Therefore, interpreting the Scriptures means looking for and finding out the sense and spiritual messages from the text. A small part of the spiritual sense of the Scriptures can be directly seen in what is written, through literal interpretation. However, most of them are hidden behind the text. Thus, the literal interpretation alone is not enough, and are even irrelevant and dangerous especially in the case of verses that contain violence. Consequently, the allegorical interpretation should be an obligation. Even so, it should be noted that looking for and acquiring the meaning behind the text is not easy and can be inaccurate or very subjective. Thus, this second method should be done together with the first method, "esegesi orante", so that the obtained allegorical sense would be truly spiritual and in accordance with the will of God.

52 Cf. Daniel Sheerin, The Role of Prayer in Origen's Homilies, in Origen of Alexandria. HisWorld and His Legacy, edd. C. Kannengieser-W. L. Petersen, Notre Dame 1988, 200-214. 
Third, there is the Scripture interprets Scripture method. Although consisting of many books and written in different times by the different situations and different human writers, the Scriptures are one Book as a whole. God, whose words were written in all the Scriptures, is the only one and the same God. For that reason, in the interpretation of the Scriptures, every word or verse should not be interpreted in pieces, as if they were independent and isolated on their own. Every word and verse, even though it seems to contain contradictions, should be interpreted in harmony with the general and the main message of the Scriptures which is love. In this case, a word or a verse in one part of the Scriptures that sounds absurd could be interpreted using the words or verses in the other part that has clear sense. That is why, this method is known as Scripture interprets Scripture.

Lastly, there is the criteria of $\dot{\omega} \varphi \varepsilon ́ \lambda \varepsilon \iota \check{\alpha}$ (opphéleia: benefit). These criteria underline that the interpretation of the Scriptures, should provide benefits, for the interpreter, the listeners, and the society in general. Thus, a good interpreter, while interpreting the Scriptures and proclaiming the sermons, should think about its impact and outcome, which is to increase the knowledge and the quality of faith, both personal and communal, as well as contributing to the common good. It is obvious then, interpreting the violence verses of the Scriptures to justify and trigger new acts of violence, is absolutely wrong. This kind of interpretation is not in accordance with the principle of "benefit". Thus, even if the violence, war, killing and destruction, described in the Scriptures really happened, they should only have happened in the past and not reoccur in the present.

This patristic exegesis offers an alternative method of interpretation to the historical-critical method suggested by many scholars. ${ }^{53}$ Furthermore, it also could be an alternative for those who do not accept the historical-critical method. The Catholic Church itself highly appreciates the patristic exegesis. In fact, Pope Benedict XVI, in his book "Jesus of Nazareth", asserted that the historical-critical method alone was not sufficient to interpret the Scriptures. ${ }^{54}$ He called for the Scriptures to

53 This method is attentive to the historical development of texts or traditions across the passage of time (historical approach) and used the scientific criteria for analyzing the texts such as textual criticism, literary criticism, critical study of forms, and redaction criticism (critical approach). Joseph A. Fitzmayer, ed., The Biblical Commision's Document, "The Interpretation of the Bible in the Church". Text and Commentary, (Roma: Pontificio Istituto Biblico 1955) 26-49.

54 Joseph Ratzinger, Jesus of Nazareth, (New York: Double Day 2007) xxiii. 
be read theologically as the Church Fathers did. Thus, he praises, "new attempts to recover patristic exegesis and to include renewed forms of a spiritual interpretation of Scripture". ${ }^{55}$

\section{Bibliography}

Anderson, Tom H.C., "Text analysis answers: Is the Quran really more violent than the Bible? (Part 2 of 3)," (20 January 2016). https://odintext.com/ blog/blog/textanalysisbible2of3 (acces 5.11.2019).

Azra, Azyumardi, Islam Reformis: Dinamika Intelektual dan Gerakan (Jakarta: Raja Grafindo Persada 1999).

Bal, Mieke, ed., Anti-Covenant: Counter-Reading Women's Lives in the Hebrew Bible, (Sheffield: The Almond Press 1989).

Blowers, Paul M., Exegesis and Spiritual Pedagogy in Maximus Confessor: An Investigation of the Quaestiones ad Thalassium (Notre Dame: University of Notre Dame Press 1991).

Brewitt-Taylor, Sam, Christian Radicalism in the Church of England and the Invention on the British Sixties, 1957-1970: The Hope of a World Transformed (Oxford: Oxford University Press 2018).

Bruce, Steve, Fundamentalism (Cambrigde: Pality Press 2000).

Castagno, Adele Monaci, ed., Origene. Dizionario: la cultura, il pensiero, le opere, (Roma: Città Nuova 2000).

Cocchini, Francesca, Origene. Teologo esegeta per una identità cristiana (Bologna: EDB 2006).

Crouzel, Henry, Origene (Roma: Borla 1985).

Danielou, Jean, From Shadows to Reality. Studies in the Biblical Typology of the Fathers (London: Burn \& Oates 1960).

Demircan, Adnan \& Rifat Atay, s.v. Tafsir in Early Islam, in The Qur'an: An Encyclopedia, ed. O. Leaman (London \& New York: Routledge 2006) 624-631.

Fitzmayer, Joseph A., ed., The Biblical Commision's Document, "The Interpretation of the Bible in the Church". Text and Commentary, (Roma: Pontificio Istituto Biblico 1955).

Formichi, Chiara, "(Re) Writing the History of Political Islam in Indonesia”, Jour-

55 Cardinal Joseph Ratzinger, "Preface to the Pontifical Biblical Commission," The Interpretation of the Bible in the Church, Pontifical Biblical Commission (13 April 1993). https: / / catholic-resources.org/ ChurchDocs/PBC_Interp-FullText.htm\#Preface (acces 9.9.2019). 
nal of Social Issues in Southeast Asia 30, No. 1 (2015). DOI: 10.1355/ sj30-ld (acces 26.02.2020).

Hasan, Mubashar, Kenji Isezaki and Sameer Yasir (eds.), Radicalization in South Asia: Context, Trajectories and Implications (New Delhi, California: SAGE Publications) 2019.

Iborra, Manuel Mira, "La Uccisione dei discendenti di Saul (2 Sam. 21,1-14) nella Quaestio ad Thalassium LXV," Cristianesimo e violenza: gli autori cristiani di fronte a testi biblici 'scomodi'. XLIV Incontro di Studiosi dell'Antichità Cristiana: Roma, 5-7 maggio 2016 (Roma: Institutum Patristicum Augustinianum 2018) 209-234.

Ilyas, Hamim "Akar Fundamentalisme dalam Perspektif Tafsir Al-Quran", Kata Pengantar in Jack Nelson Pallmayer, Is Religion Killing Us?: Membongkar Akar Kekerasan dalam Bibel dan Qur'an, trans. \& ed. Hatib Rachmawan, Bobby Setiawan, and Iskandar Zulkarnain (Yogyakarta: Pustaka Kahfi 2007).

Louth, Andrew, Maximus the Confessor (London \& New York: Routledge 1996).

Mahendra, Yusril Ihza, Modernisme dan Fundamentalisme dalam Politik Islam; Perbandingan Partai Masyumi (Indonesia) dan Partai Jamâ'at-i-Islâmî (Pakistan), (Jakarta: Paramadina 1999).

Maximus the Confessor, On Difficulties in Sacred Scripture: The Responses to Thalassios, trans. Constas, Maximos, (Washington D.C.: The Catholic University of America Press 2002).

Nautin, Pierre, Origène. Sa vie e son oeuvre (Paris: Beauchesne 1977).

Origen, Homilies on Jeremiah, trans. John Clark Smith (Washington D.C.: The Catholic University of America Press 1998).

Origen, Homilies on Joshua, trans. \& ed. Barbara J. Bruce \& Cynthia White (Washington D.C.: The Catholic University of America Press 2002).

Origen, Homilies on Luke, Fragmens on Luke, trans. Joseph T. Lienhard (Washington D.C.: The Catholic University of America Press 1996).

Origen, Homilies on Numbers, trans. \& ed. Thomas P. Scheck \& Christopher A. Hall (Illionis: InterVarsity Press 2009).

Origen, On First Prinsiples, Book IV, trans. J. Behr (Oxford: Oxford University Press 2017).

Pauline Allen \& Bronwen Neil, ed. The Oxford Handbook of Maximus the Confessor (Oxford: Oxford University Press 2015). 
Perone, Lorenzo, La preghiera secondo Origene, l'impossibilit donata (Brescia: Morcelliana 2001).

Ratzinger, Cardinal Joseph, "Preface to the Pontifical Biblical Commission," The Interpretation of the Bible in the Church, Pontifical Biblical Commission (13 April 1993).

Ratzinger, Joseph, Jesus of Nazareth, (New York: Double Day 2007).

Sheerin, Daniel, The Role of Prayer in Origen's Homilies, in Origen of Alexandria. His World and His Legacy, edd. C. Kannengieser-W. L. Petersen, (Notre Dame: University of Nitre Dame Press) 1988, 200-214.

Simonetti, Manlio, Origene esegeta e la sua tradizione (Brescia: Morcelliana 2004)

Simonetti, Manlio, s.v. Exegesis, Patristic, in Encyclopedia of Ancient Christianity, ed. Angelo di Berardino (Illionis: IVP Academic 2014) 897-903.

Simut, Corneliu C., Traditionalism and Radicalism in the History of Christian Thought (New York: Palgrave Macmillan) 2010.

Spong, John Shelby, The Sins of Scripture: Exposing the Bible's Texts of Hate to Reveal the God of Love, (NY: HarperOne; HarperCollins), 2005.

Sulistiyono, Susilo \& Reza Pahlevi Dalimunthe, "Moderate Southeast Asian Islamic Education as a Parent Culture in Deradicalization: Urgencies, Strategies, and Challenges", Religions 10, 45 (2019), doi:10.3390/ rel10010045 (acces 23.02.2020).

Trigg, Joseph W., Origen (London \& New York: Routledge 1998).

Van Beek, Martijn, "Dangerous Liaisons: Hindu Nationalism and Buddhist Radicalism in Ladakh", ReseachGate (January 2004).https://www.researchgate.net/publication/288913917Dangerous_Liaisons_Hindu_Nationalism_and_Buddhist_Radicalism_in_Ladakh (acces 26.02.2020).

Van Dijk, Cornelis, Rebellion under the Banner of Islam. The Darul Islam in Indonesia (Leiden: Martinus Nijhoff 1981). https://www.jstor.org/stable/10.1163/j.ctvbqs6vx (acces 26.02.2020).

Zuhdi, Muhamad Harfin, "Fundamentalisme dan Upaya Deradikalisasi Pemahaman Al-Qur'an dan Hadis”, Religia 13, Nr. 1 (2010) 81-102. 
